\title{
The new technologies of high-throughput single-cell RNA sequencing
}

\author{
E.A. Vodiasova $\otimes$, E.S. Chelebieva, O.N. Kuleshova \\ A.O. Kovalevsky Institute of Biology of the Southern Seas, RAS, Moscow, Russia \\ هe-mail: eavodiasova@gmail.com
}

A wealth of genome and transcriptome data obtained using new generation sequencing (NGS) technologies for whole organisms could not answer many questions in oncology, immunology, physiology, neurobiology, zoology and other fields of science and medicine. Since the cell is the basis for the living of all unicellular and multicellular organisms, it is necessary to study the biological processes at its level. This understanding gave impetus to the development of a new direction - the creation of technologies that allow working with individual cells (single-cell technology). The rapid development of not only instruments, but also various advanced protocols for working with single cells is due to the relevance of these studies in many fields of science and medicine. Studying the features of various stages of ontogenesis, identifying patterns of cell differentiation and subsequent tissue development, conducting genomic and transcriptome analyses in various areas of medicine (especially in demand in immunology and oncology), identifying cell types and states, patterns of biochemical and physiological processes using single cell technologies, allows the comprehensive research to be conducted at a new level. The first RNA-sequencing technologies of individual cell transcriptomes (scRNA-seq) captured no more than one hundred cells at a time, which was insufficient due to the detection of high cell heterogeneity, existence of the minor cell types (which were not detected by morphology) and complex regulatory pathways. The unique techniques for isolating, capturing and sequencing transcripts of tens of thousands of cells at a time are evolving now. However, new technologies have certain differences both at the sample preparation stage and during the bioinformatics analysis. In the paper we consider the most effective methods of multiple parallel scRNA-seq using the example of 10XGenomics, as well as the specifics of such an experiment, further bioinformatics analysis of the data, future outlook and applications of new high-performance technologies. Key words: scRNA-seq; transcriptomics; Chromium 10XGenomics; sequencing; single cell.

For citation: Vodiasova E.A., Chelebieva E.S., Kuleshova O.N. The new technologies of high-throughput single-cell RNA sequencing. Vavilovskii Zhurnal Genetiki i Selektsii = Vavilov Journal of Genetics and Breeding. 2019;23(5):508518. DOI 10.18699/VJ19.520

\section{Новейшие технологии высокопроизводительного секвенирования транскриптома отдельных клеток}

\author{
Е.А. ВоАясова 囚, Э.С. Челебиева, О.Н. Кулешова \\ Институт биологии южных морей имени А.О. Ковалевского Российской академии наук, Москва, Россия \\ 凶e-mail: eavodiasova@gmail.com
}

\begin{abstract}
Огромное количество полногеномных и транскриптомных данных, полученных с помощью современных технологий секвенирования нового поколения для целых организмов, не смогло дать ответы на многие вопросы в онкологии, иммунологии, физиологии, нейробиологии, зоологии и других областях науки и медицины. Так как основой всех одноклеточных и многоклеточных организмов является клетка, то необходимо изучение биологических процессов на ее уровне. Это понимание дало толчок развитию нового направления и появлению технологий, позволяющих работать с единичными клетками (технологии single-cell). Быстрое развитие не только приборной базы, но и различных усовершенствованных протоколов для работы с единичными клетками обусловлено актуальностью этих исследований во многих областях науки и медицины. Изучение особенностей различных этапов онтогенеза, определение закономерностей дифференциации клеток и последующего развития тканей, проведение геномного и транскриптомного анализов в различных областях медицины (особенно востребовано в иммунологии, онкологии), классификация типов и состояний клеток, закономерностей биохимических и физиологических процессов с применением технологий single-cell позволяют проводить комплексные исследования на новом уровне. Разработанные первые платформы для осуществления секвенирования транскриптомов отдельных клеток (scRNA-seq) проводили изоляцию не более ста клеток единовременно, что оказалось недостаточным в связи с выявленной высокой гетерогенностью клеток, обнаруженными минорными типами клеток, которые не детектировались по морфологическим признакам, и сложными регуляторными путями в организме. В настоящее время появились методики изоляции, захвата и секвенирования транс-
\end{abstract}




\begin{abstract}
криптомов (scRNA-seq) десятков тысяч клеток единовременно. Однако новые технологии имеют определенные отличия как на этапе пробоподготовки, так и во время проведения биоинформатического анализа. В работе рассмотрены наиболее эффективные методы множественного параллельного scRNA-seq на примере современной платформы для изоляции и баркодирования клеток 10XGenomics, а также особенности проведения такого эксперимента, дальнейший биоинформатический анализ полученных данных, перспективы использования и области применения новых высокопроизводительных технологий.

Ключевые слова: scRNA-seq; транскриптомика; Chromium 10XGenomics; секвенирование; единичные клетки.
\end{abstract}

\section{Introduction}

The improvements in new generation sequencing technology in conjunction with the technology of multiple parallel capture and analysis of single cells raised to a new level of research in many fields of biology, biotechnology and medicine (Junker, Oudenaarden, 2014). A brief history of the development of single-cell biology is presented in the Fig. 1. The main areas of the application of innovative methods are neurobiology, immunology, embryology and oncology. The first experiments on the analysis of the transcriptome of single neurons were carried out using microarrays in 2003. Isolation of neurons were captured using laser capture microdissection instrument and data analysis revealed the unexpectedly high cellular heterogeneity (Kamme et al., 2003). The sequencing of the neuron transcriptome began to actively develop (Moroz et al., 2006; Tang et al., 2009) and at the same time microfluidic technology that allow the analysis of up to 100 cells simultaneously appeared (Marcus et al., 2006). In parallel convergence of qPCR and single-cell methods are implemented (Subkhankulova et al.,
2008). The first whole genomic sequencing of tumor cells identified unexpectedly abundant subpopulation of 'pseudodiploid' cells which do not metastasize (Navin et al., 2011). In the past five years, a new trend of "epigenomics" has been developed, connected with the study of various RNA and DNA modifications using sequencing. Modern singlecell technology allows to characterize the methylation, chromosome organization, intra- and interdomain contacts, chromatin mobility, specific sites of histone modifications in single-cell resolution (Goldberg et al., 2007; Nagano et al., 2013; Rotem et al., 2015).

The need for an analysis of a huge number of cells in parallel has led to the development of high-throughput technologies aimed at increasing the sensitivity and accuracy of sequencing by using different protocols and developing platforms for capturing single cells with high efficiency. From 2003 to 2016, the number of captured cells simultaneously increased from a few to hundreds of thousands.

Analysis of the transcriptome, proteome and epigenome at the single-cell resolution allows to understand the formation,

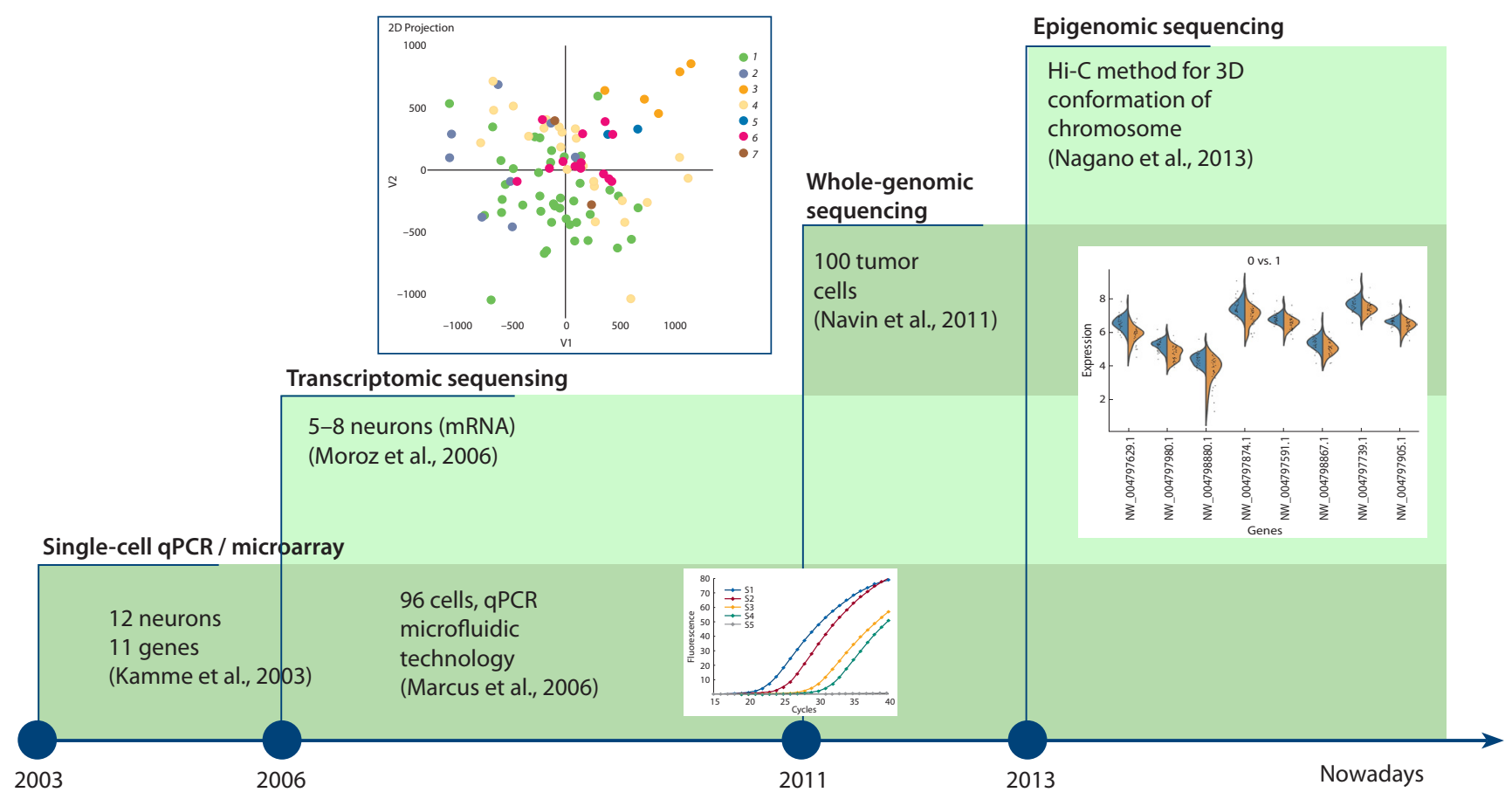

Fig. 1. The overview of the development of single-cell technologies. 


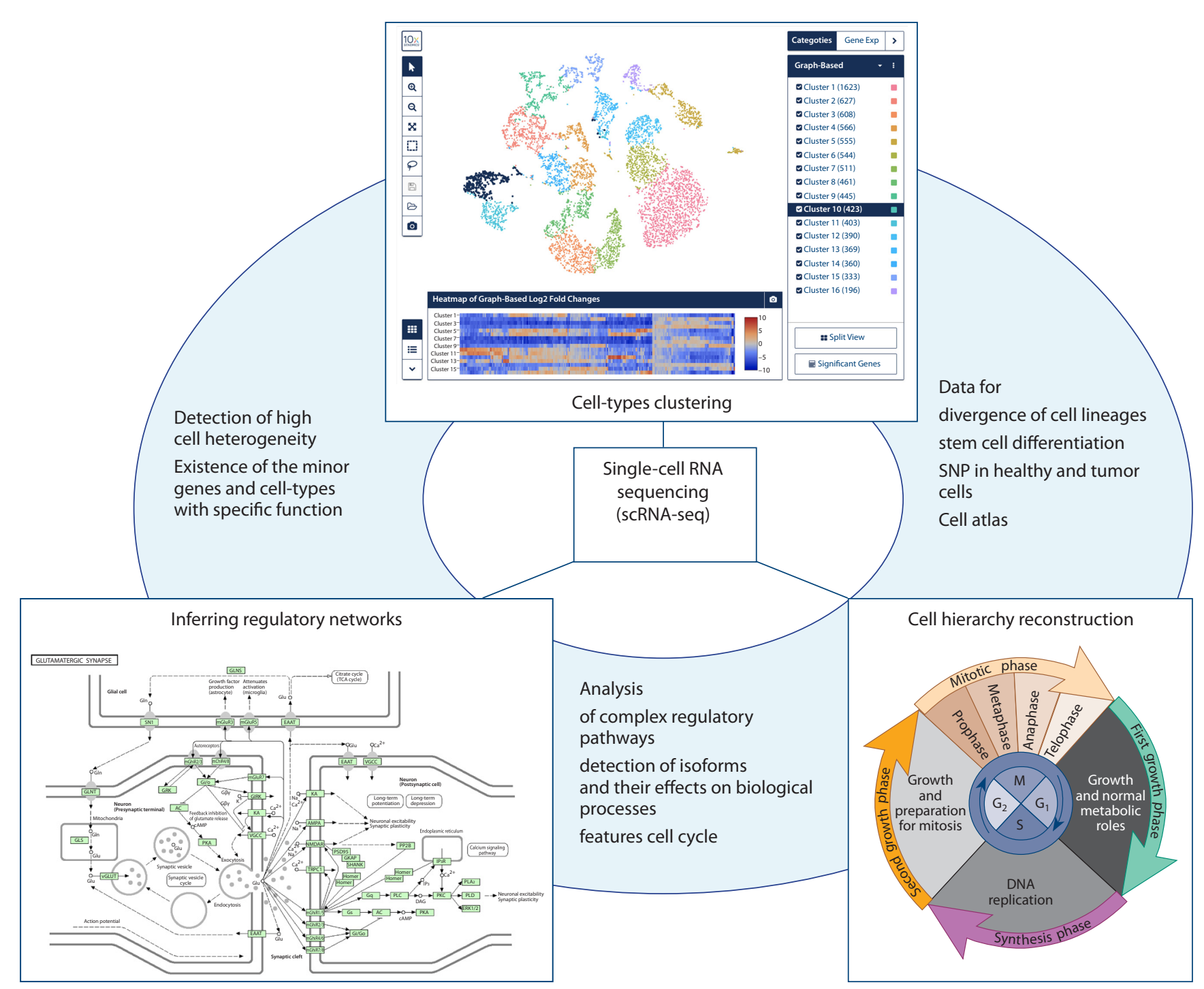

Fig. 2. The main applications of scRNA-seq data analyses.

development, organization and interaction of various cells and tissues, explore the problems of stress and adaptations (Frieda et al., 2017), identify the types and states of cells, establish patterns of their differentiation in the ontogeny (Nowogrodzki, 2017; Mi et al., 2018), study various diseases in immunology, oncology, neurobiology and other fields of medicine (Leung et al., 2017), answer questions of evolution, speciation and formation of global biodiversity (Moroz, 2018).

In this article we briefly review some of the latest and most efficient commercial available platforms for single cell collection. The capturing and specific protocols for single-cell RNA-sequencing (scRNA-seq) as well as the bioinformatics analysis and application of single-cell technologies are considered.

\section{Applications of single-cell RNA-seq technologies}

The main areas and approaches for scRNA-seq data in various fields of biology and medicine are presented in the Fig. 2. Bioinformatics pipelines for scRNA-seq data allow to analyze different regulatory networks based on gene expression of different genes for all single cell (Janes et al., 2010; Shalek et al., 2013; Trapnel et al., 2014; Treutlein et al., 2014). Also, the new single-cell technology focuses in identification of cell-types and cell-stages (Jaitin et al., 2014), revealing rare genes and cell populations, which can be discarded from analysis of bulk transcriptome as minor fractions (Gerber et al., 2016), point mutations (Gawad et al., 2016; Ludwig et al., 2019).

Today, due to the expression profiles of thousands of genes in hundreds of thousands of individual cells, unique cell-types and cell-states have been identified, new signaling pathways have been uncovered (Saliba et al., 2014; Grun et al., 2015; Okaty et al., 2015; Zeisel et al., 2015; Poulin et al., 2016; Tirosh et al., 2016; Callaway, 2017; Lavin et al., 2017). The whole-organism tissue maps at the single-cell level are now constructed (Segal et al., 2004; Pijuan-Sala et al., 2019; Taylor et al., 2019), cell lineages reveal high heterogeneity (Mahata et al., 2014; Wang, Song, 2017).

The combination of various molecular methods with 
scRNA-seq technology now are leading the experiments to the fundamentally new level. So, to study the cell-states and cells differentiation during ontogenesis, it is possible to use the CRISPR-Cas9 system for barcoding by the introduction of specific mutations into the genome or various fluorescent labels (Adamson et al., 2016; Jaitin et al., 2016; McKenna et al., 2016; Kalhor et al., 2017). It has been shown that long non-coding RNAs, even in several copies in a cell, may have important regulatory functions (Derrien et al., 2012). The capturing of thousands of cells and high-throughput sequencing with the detection of chromosome organization in the three-dimensional space (Hi-C) (Belton et al., 2012) shown, that chromosomal compartments, contact insulation, topological-associated domains (TADs) or long-range loops are governed by distinct cell-cycle dynamics (Nagano et al., 2017; Stevens et al., 2017).

\section{Platform for single-cell collection}

The essential requirement in studying the transcriptome of individual cells is the dissociation and capture of each cell of high quality and preparation for sequencing (barcoding of all transcripts for each cell). In order to pool, amplify and sequence cDNA in a single run and then assign each read to its original cell at the bioinformatics analysis step, it is necessary to incorporate a unique cellular identifier. Today, single-cell isolation platforms are represented by commercial models that differ in performance: Puncher Platform Vycap, CellRaft AIR System, PEPArray System, Fluidigm C1, Wafergen ICELL8, BioRad Illumina ddSEQ, Dolomite Bio Nadiа и RNA-Seq System, Tapestri Platform MissionBio, 1CellBio InDrop, BD Rhapsody, Chromium 10XGenomics (Kolodziejczyk et al., 2015; Valihrach et al., 2018).

Single-cell isolation approaches can be divided into low-throughput (capture from 10 to 100 cells) and highthroughput (capture from 100 to $>10,000$ cells) (Wang, Navin, 2015; Poulin et al., 2016). The first group includes serial dilution (Ham, 1965), mechanical micromanipulation (Brehm-Stecher et al., 2004), micropipetting, laser capture microdissection (LCM); the second group: fluorescence activated cell sorting (FACS), microfluidics, microdroplets (Navin et al., 2011; Landry et al., 2013; Mazutis et al., 2013). We consider here highly efficient cell capture platforms them in more detail as the most popular. FACS is method based on the size, granularity and fluorescent properties of cells, which allows to isolate hundreds of thousands of cells per minute, so it is as efficient as economical. However, the use of fluorescent dye can negatively affect cell viability (Lindström et al., 2010).

The methods for cell isolation based on microfluidics and microdroplets technologies are actively developing and used in the analysis of not only the transcriptome, but also the whole-genome of individual cells, as well as epigenomics sequencing (Zheng et al., 2017). These integrated systems allow to manipulate small volumes $\left(10^{-9}-10^{-18} 1\right)$, isolate DNAand output accurate results with high resolution (Whitesides et al., 2006; Salafi et al., 2016). Today there are a lot of high-throughput commercial platforms for cell isolation based on microfluidics technology, which not only capture cells but also provide further biochemical reactions (Poulin et al., 2016; Valihrach et al., 2018).

A droplet-based system became breakthrough in singlecell RNA sequencing and now we can label all mRNA molecules with barcode sequence shared for the same cell. It gives the ability to analyze huge number of cells in parallel and check the cell origination for each mRNA. Such approach is implemented in the next devices: Drop-Seq (Macosco et al., 2015), InDrop (Klein et al., 2015) and Chromium 10XGenomics (Kolodziejczyk et al., 2015). It is based on technology that separates high molecular weight DNA fragments or whole single cells into emulsifications containing beads with attached adapters and unique barcodes (Coombe, 2016). As a result, we obtain a suspension of gel beads (GEM - Gel bead in EMulsion), in each of which there is one cell and all the necessary reagents for lysis, barcoding, reverse transcription and cDNA synthesis. The main advantage of these platforms is the high efficiency of the capture and preparation of single cells for further sequencing. One of the leaders in this area is Chromium 10XGenomics, which allows you to simultaneously capture up to $80,000+$ cells, while the number of cells analyzed from other high-performance platforms ranges from 10,000 to 48,000 cells (Valihrach et al., 2018).

\section{Single-cell mRNA sequencing with high-throughput platforms}

The study of single cell transcriptome consists of experimental and bioinformatics parts (Kumar et al., 2017; Li et al., 2017). Before starting an experiment, it is necessary to have a reference genome or bulk transcriptome for mapping of scRNA-seq data (Gawad et al., 2014). As mentioned above, the most productive platform is Chromium ${ }^{\mathrm{TM}} 10 \mathrm{XGenom-}$ ics. The features of the scRNA-seq experiment based on it in comparison with other methods for studying individual cells are discussed below.

\section{Cell isolation and scRNA methods}

The main challenge of sample preparation is to obtain a suspension of viable non-aggregated cells (cell dissociation). It is necessary to determine the concentration of cells, since a successful capture requires a certain number of them depending on the chosen method of cell isolation: from ten cells (micropipetting, cytoplasmic aspiration, laser microdissection) to thousands of cells (devices based on FACS technology, microfluidics and microdroplets) (Der et al., 2017). In the case of working with high-throughput devices (for example, Chromium 10XGenomics), the cell concentration should be about 1,000,000 cells/ml (Der et al., 2017). When working with animals or tissues containing the number of cells less than the required, you need to increase the number of specimen per sample. All stages of cell dissociation are carried out in a minimum volume of solution (from 50 to $1000 \mu \mathrm{l}$ ) to increase the concentration and reduce cell loss. 
Single-cell RNA sequencing protocol may be divided into three stages: reverse transcription, cDNA amplification (WTA - full-transcriptome amplification) and library preparation. Despite the undesirability of cDNA amplification (due to the possibility of polymerase errors or the loss of rare transcripts), this step is necessary to construct a cDNA library, because the amount of total RNA in the cell is about $10 \mathrm{pg}$, which is not enough for single cell transcriptomic sequencing (Wang, Song, 2017). Protocols for reverse transcription and cDNA amplification depends on the task and platform for cell isolation (Haque et al., 2017; Kumar et al., 2017; Ziegenhain et al., 2017).

Today, three approaches are known. The first is oligodT-anchor approach (or Tang's method). It uses oligo-dTprimers conjugated to adapter sequence for reverse transcription and selective amplification of polyadenylated mRNA by PCR (Tang et al., 2009). However, this protocol leads to missing proximal splicing event due to the generation of 3 '-end skew bias during reverse-transcription.

Later, the approach that allows to construct a full-length cDNA was developed - it is called template switching cDNA synthesis (Ramsköld et al., 2012). The main benefit is in ability to detect alternatively spliced exons and allelespecific expression (ASE) (Kolodziejczyk et al., 2015). This approach is used in such protocols as STRT (Islam et al., 2014), SMART-seq и SMART-seq2 (Ramcköld et al., 2012; Deng et al., 2014). The key features of these protocols is the exponential increase in the number of transcripts during the amplification, that leads to bias and loosing of minor expressed genes. In vitro transcription (IVT) is the alternative approach with linear amplification which incorporated to a such protocols as CEL-Seq (Hashimshony et al., 2012) and MARS-Seq (Jaitin et al., 2014).

Finally, the third approach based on using a 6-10 bp unique molecular identifier (UMI) with anchored oligodT- primer for barcoding each molecule. This labeling technology is presented in CEL-Seq (Hashimshony et al., 2012) and CEL-Seq2 (Hashimshony et al., 2016), Drop-Seq (Macosco et al., 2015), MARS-Seq (Jaitin et al., 2014), SCRB-seq (Soumillon et al., 2014), STRT (Islam et al., 2014), In-Drop (Klein et al., 2015). Quartz-Seq2 (Sassagawa et al., 2018), the one of the latest protocols with UMI, allows to pool cDNA of up to 1536 cells into one mixture and the UMI conversion efficiency is $35 \%$ in contrast with $22 \%$ for the other scRNA-seq method. It gives the opportunity to effectively convert initial reads to UMI counts and detect more genes.

The modern tools for isolation and capturing hundreds of thousands of cells require an improvement in the labeling of mRNA molecules. The most innovative barcoding strategy in microfluidic and microdroplet technology is the use of as UMI as an additional cellular barcode placed in each drop with individual cells and other reagents. The cellular barcode (about 14 bp oligonucleotide) is an identifier of all nucleotide sequences from different cell. The advantage of such double barcoding is the high accuracy and the ability to assign each mRNA to its original cell (Islam et al., 2014). The sequencing protocol STAMPs (Single-cell Transcriptomes Attached to Microparticles) was designed for platform Drop-Seq and protocol Cell-Seq for platform InDrop (Wang, Song, 2017).

The most high-throughput commercial platform for cell isolation Chromium 10XGenomics integrated the new barcoding technology GemCode. After isolation of cells, each long molecule is labeled with oligonucleotide, which consists of sequencing adapters and primers, a unique molecular identifier with anchored oligo-dT and a barcode to index GEMs, before library preparation (Eisenstein, 2015; Coombe et al., 2016). The double barcoding leads to reducing technical noise during the analyzing of thousands of different cells in parallel. It is especially important when working with complex tissues on a single-cell resolution and you need to get detailed information about cell-to-cell variability. This makes it possible to determine gene expression profiles, alternative splicing and cellular heterogeneity (Zheng et al., 2017).

Also, it is known various adapters for small RNA sequencing library preparation: for example, a pre-adenylated 3 '-end adapter containing a 5',5'-adenyl pyrophosphoryl moiety (Hafner et al., 2008; Chen et al., 2012).

cDNA preparation is followed by sequencing. The choice of sequencing technology should be directly dependent on the goals. The different lengths of the reads (from fifty to several thousand nucleotides), accuracy, efficiency should be considered before choosing a sequencing method (Liu et al., 2012).

\section{Computational analyses}

The development of high-throughput cell isolation platforms, capturing hundreds of thousands of cells, requires new bioinformatics approaches to analyze so massive and complex single-cell transcriptomic data sets. It should be noted that in the analysis of scRNA-seq it is not always possible to use traditional computational tools for the bulktranscriptome. In the sections below, we discuss the challenges single-cell transcriptomics and possible solutions.

A single scRNA-seq experiment is able to provide information about the profiling of all RNAs present in each of hundreds of thousands of cells, which leads to generation of massive volume of data and technical difficulties in analyzing them. The alignment and counting of reads is performed independently per cell, which requires more challenging parallelism and, accordingly, more computational power (Tokunaga et al., 2014; Yu, Lin, 2016).

scRNA-seq allows you to analyze the expression profiles for each individual cell. This led to the emergence of three main areas of application single-cell transcriptomics (see Fig. 2): identification of cell populations (cell-types and cellstates), the cell hierarchy reconstruction (cell differentiation during embryogenesis or cell responses to various stimulus) and inferring regulatory networks (based on gene expression) (Stegle et al., 2015). Each of these tasks is reduced to the following stages of bioinformatics analysis: quality control of reads, filtering, alignment and mapping to the 


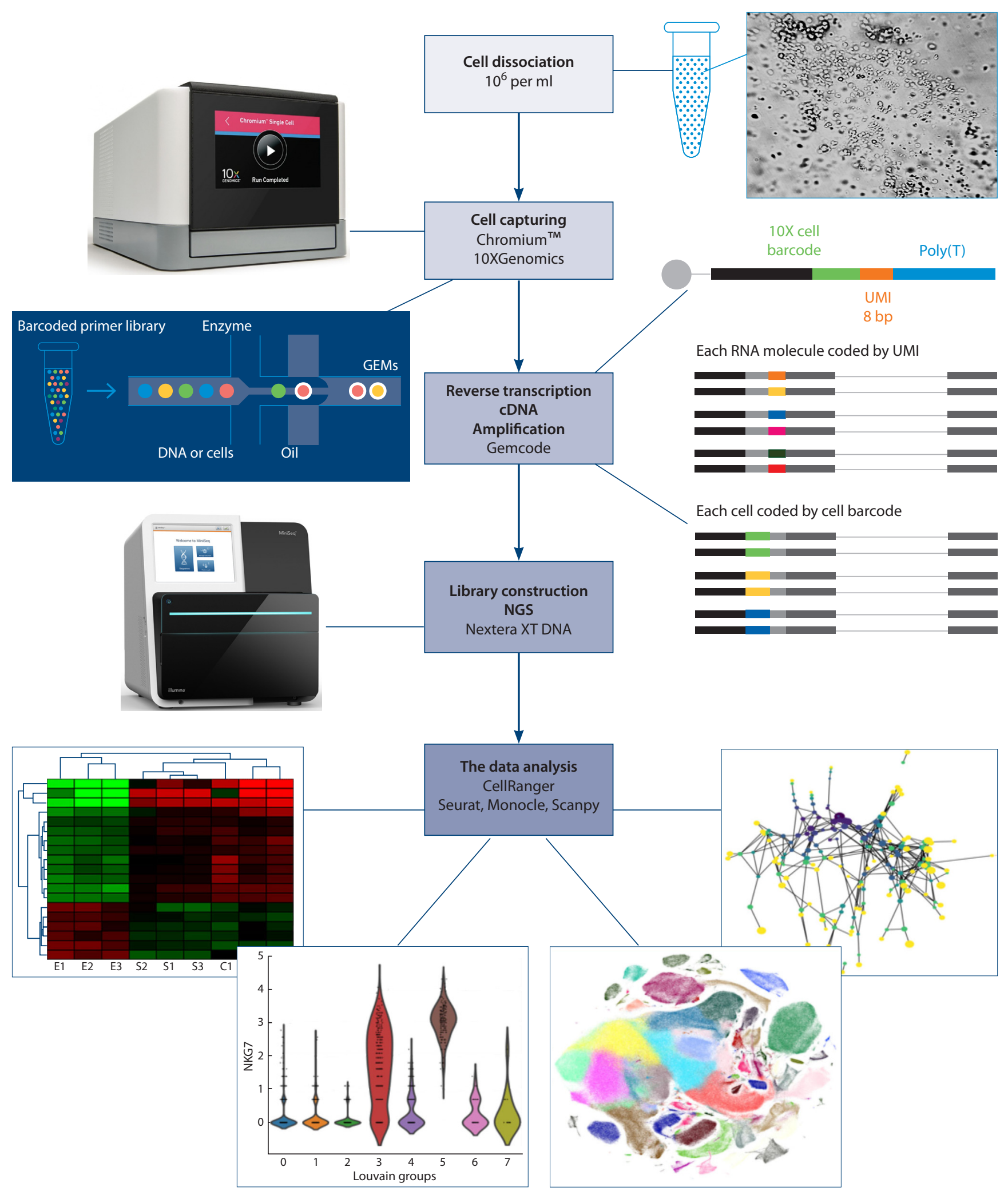

Fig. 3. The process of single-cell RNA-seq experiment using the powerful platform for capturing cell Chromium 10XGenomics.

reference genome/transcript, formation of a matrix of read counts, dimension reduction, normalization, searching for external factors introducing an error in the analysis, clustering cells, searching for marker and high variable genes, analysis of differential expression and transcript isoforms, search for correlations in the expression of various genes (Stegle et al., 2015; Hwang et al., 2018). It is possible to use standard programs and approaches developed for bulk transcriptome for some goals. 
Before interpretation of single cell expression profiles, it is necessary to incorporate technical variability estimates. The confounding factors can be divided into two categories: technical noise (for example, different cell capture efficiency, duplicated reads, dropout - missed transcript during the reverse-transcription step, batch effect - systematic differences arising as a result of sample preparation) and biological factors (stochastic gene expression, cell cycle, environment condition) (Stegle et al., 2015; Andrews, Hemberg, 2018; Hwang et al., 2018).

A specific feature of the protocols for capturing cells is the probability that two cells fall into one drop, GEM (1-10\% depending on the type of platform used), which leads to the appearance of doublets during the transcriptomic sequencing and an error during cell-types identification (Segerstolpe et al., 2016). On the other hand, the degradation of mRNA during cell/tissues dissociation or bad-quality lysis also can result in wrong classification (Brennecke et al., 2013; Hwang et al., 2018). So, such clusters of cells must be excluded from analysis during transcript quantification and quality control. The most effective is the use of protocols in conjunction with the unique molecular identifiers (UMI) (Hashimshony et al., 2012; Macosco et al., 2015) and exogenous RNA spike-ins at known concentrations and sequence which are added to each cell extract in RNA sequencing experiment (Jiang et al., 2011). It is exploited to estimate of absolute transcript counts from observed read count and normalize gene expression levels (Stegle et al., 2015). Also, you can identify confounders and technical variability in order to reduce errors during comparing expression profiles by increasing the number of biological replicates.

Using the endogenous mRNA allows to estimate the total mRNA content of each cell during normalization (Stegle et al., 2015). The most commonly used approaches for normalization include RPKM (Mortazavi et al., 2008), FPKM, TPM (Li et al., 2010). TMM and DESeq are alternative scaling factors (Robinson, Oshlack, 2010; Li et al., 2012). At the same time, normalization methods were developed for data scRNA-seq (Lun et al., 2016; Bacher et al., 2017).

Since, a huge amount of data is made during the single-cell transcriptomic sequencing for all genes in thousands of cells, creates difficulties in statistical analysis. Therefore, an important step in working with such data is the choice of a good dimension reduction strategy (Andrews, Hemberg, 2018). There are two main approaches: dimensionality reduction and removing uninformative genes. The first are: principal component analysis - PCA (Pierson, Yau, 2015); stochastic method - tSNE (Maaten, Hinton, 2008); diffusion maps DM (Moon et al., 2018). To identify features of interest you may search highly variable genes (HGV), estimate dropout rate by Michaelis-Menten modeling of dropouts (M3Drop), analyze positive or negative correlation of gene expression cell-to-cell, use spike-in based methods (Andrews, Hemberg, 2018). Some programs combine several methods that is more effective (for example, PAGODA) (Fan et al., 2016).

It is known that the bias during clustering cell and identification novel cell-types can be caused by the stage of cell cycle. Thus, the observed expression profile is different for G1 and G2 (Stegle et al., 2015).

The construction of regulatory networks and the reconstruction of the cell hierarchy cannot be performed for bulk transcriptomic data. The algorithm is based on the ordering of transcriptional states of various cells, which are located on a trajectory (e. g. Monocle) that characterizes a developing biological process in the organism, for example, apoptosis (Haghverdi et al., 2016).

There are some software packages available for analyzing single cell transcriptomic data step by step (Valihrach et al., 2018). So for Chromium 10XGenomics, the developer provides the CellRanger software pipeline (Zheng et al., 2017); for Drop-Seq, the developer does not propose software for primary analysis, but there are several third-party developments, for example, zUMIs (Parekh et al., 2018), scPipe (Tian et al., 2018), Dr.Seq2 (Zhao et al., 2017).

The most popular software packages for analysis of scRNA-seq data are Seurat (Butler et al., 2018) and Monocle (Qiu et al., 2017). Seurat is a software package that provides quality control, dimension reduction, analysis and estimation of genes expression. The software includes three components: uncontrolled clustering and detection of cell types and states, spatial reconstruction of single cell data and integrated analysis of scRNA-seq by conditions, technologies and types. Monocle is a comprehensive software package that provides tools for analyzing experiments with single cell genes expression. However, these software packages do not scale for accessible large sets with numbers in excess of a million cells, combining data and comparative analyses. Scanpy is an alternative approach, which overcomes this limitation and provides similar analysis capabilities (Wolf et al., 2018).

The Fig. 3 illustrated single cell transcriptomic experiment step by step using droplet-based commercial platform Chromium 10XGenomics.

Despite the rapid progress of single-cell technologies in recent years, experimental and computational tools may lead to errors during various stages of the scRNA-seq experiment (Fustin et al., 2013; Nikolenko et al., 2013; Schwartz et al., 2013; Gawad et al., 2014, 2016; Poulin et al., 2016). It must be taken into account in planning and computational analysis.

\section{Conclusion}

Thus, the single cell transcriptomic sequencing reveals the differences in genes expression profiles not only in the cell of various tissues, but also during ontogenesis as well as under changing external conditions. Due to the cell resolution, the scRNA-seq technologies are currently actively used in various fields of biology and medicine. It is innovative for investigation of convergent evolution mechanisms, different evolutionary origins and changes in cell lines of various taxonomic groups, identification of new cell-types and their functions. It is shown the need for complex researches, for example, whole organisms, tumors or tissues, which requires the development transcriptome sequencing technologies 
for a huge number of cells in parallel. Nowadays the main criteria for the technology of scRNA-seq is the efficiency for capturing and barcoding cells. The most innovative and efficient for today is the commercial platform Chromium 10XGenomics with integrated GemCode technology, which allows such an analysis to be carried out in parallel to up to eighty thousand cells.

\section{References}

Adamson B., Norman T.M., Jost M., Cho M.Y., Nunez J.K., Chen Y., Villalta J.E., Gilbert L.A., Horlbeck M.A., Hein M.Y., Pak R.A., Gray A.N., Gross C.A., Dixit A., Parnas O., Regev A., Weissman J.S. A multiplexed single-cell CRISPR screening platform enables systematic dissection of the unfolded protein response. Cell. 2016;167(7):1867-1882.e21. DOI 10.1016/j.cell.2016.11.048.

Andrews T.S., Hemberg M. Identifying cell populations with scRNASeq. Mol. Aspects Med. 2018;59:114-122. DOI 10.1016/ j.mam.2017. 07.002.

Bacher R., Chu L.-F., Leng N., Gasch A.P., Thomson J.A., Stewart R.M., Newton M., Kendziorski C. SCnorm: robust normalization of single-cell RNA-seq data. Nat. Methods. 2017;14(6):584586. DOI 10.1038/nmeth.4263.

Belton J.M., McCord R.P., Gibcus J.H., Naumova N., Zhan Y., Dekker J. Hi-C: a comprehensive technique to capture the conformation of genomes. Methods. 2012;58(3):268-276. DOI 10.1016/ j.ymeth.2012.05.001.

Brehm-Stecher B.F., Johnson E.A. Single-cell microbiology: tools, technologies, and applications. Microbiol. Mol. Biol. Rev. 2004; 68(3):538-559.

Brennecke P., Anders S., Kim J.K., Kolodziejczyk A.A., Zhang X., Proserpio V., Baying B., Benes V., Teichmann S.A., Marioni J.C., Heisler M.G. Accounting for technical noise in single-cell RNA-seq experiments. Nat. Methods. 2013;10:1093-1095.

Butler A., Hoffman P., Smibert P., Papalexi E., Satija R. Integrating single-cell transcriptomic data across different conditions, technologies, and species. Nat. Biotechnol. 2018;36(5):411-420. DOI 10.1038/nbt.4096.

Callaway A. The trickiest family tree in biology. Nature. 2017;547 (7661):20-22. DOI 10.1038/547020a.

Chen Y.R., Zheng Y., Liu B., Zhong S., Giovannoni J., Fei Z. A costeffective method for Illumina small RNA-Seq library preparation using T4 RNA ligase 1 adenylated adapters. Plant Methods. 2012;8(1):41. DOI 10.1186/1746-4811-8-41.

Coombe L., Warren R.L., Jackman S.D., Yang C., Vandervalk B.P., Moore R.A., Pleasance S., Coope R.J., Bohlmann J., Holt R.A., Jones S.J.M., Birol I. Assembly of the complete Sitka spruce chloroplast genome using $10 \times$ Genomics' GemCode sequencing data. PLoS One. 2016;11(9):e0163059. DOI 10.1371/journal.pone.0163059.

Deng Q., Ramsköld D., Reinius B., Sandberg R. Single-cell RNA-seq reveals dynamic, random monoallelic gene expression in mammalian cells. Science. 2014;343(6167):193-196. DOI 10.1126/science. 1245316

Der E., Ranabothu S., Suryawanshi H., Akat K.M., Clancy R., Morozov P., Kustagi M., Czuppa M., Izmirly P., Belmont H.M., Wang T., Jordan N., Bornkamp N., Nwaukoni J., Martinez J., Goilav B., Buyon J.P., Tuschl T., Putterman C. Single cell RNA sequencing to dissect the molecular heterogeneity in lupus nephritis. JCI Insight. 2017;2(9). pii: 93009. DOI 10.1172/jci.insight.93009.

Derrien T., Johnson R., Bussotti G., Tanzer A., Djebali S., Tilgner H., Guernec G., Martin D., Merkel A., Knowles D.G., Lagarde J., Veeravalli L., Ruan X., Ruan Y., Lassmann T., Carninci P., Brown J.B., Lipovich L., Gonzalez J.M., Thomas M., Davis C.A., Shiekhattar R., Gingeras T.R., Hubbard T.J., Notredame C., Harrow J., Guigo R. The GENCODE $\mathrm{v} 7$ catalog of human long noncoding RNAs: analy- sis of their gene structure, evolution, and expression. Genome Res. 2012;22(9):1775-1789. DOI 10.1101/gr.132159.111.

Eisenstein M. Startups use short-read data to expand long-read sequencing market. Nat. Biotechnol. 2015;33(5):433-435. DOI 10.1038/ nbt0515-433.

Fan J., Salathia N., Liu R., Kaeser G.E., Yung Y.C., Herman J.L., Kaper F., Fan J.-B., Zhang K., Chun J., Kharchenko P.V. Characterizing transcriptional heterogeneity through pathway and gene set overdispersion analysis. Nat. Methods. 2016;13:241-244. DOI 10.1038/nmeth.3734.

Frieda K.L., Linton J.M., Hormoz S., Choi J., Chow K.-H.K., Singer Z.S., Budde M.W., Elowitz M.B., Cai L. Synthetic recording and in situ readout of lineage information in single cells. Nature. 2017;541(7635):107-111. DOI 10.1038/nature20777.

Fustin J.M., Doi M., Yamaguchi Y., Hida H., Nishimura S., Yoshida M., Isagawa T., Morioka M.S., Kakeya H., Manabe I., Okamura H. RNA-methylation-dependent RNA processing controls the speed of the circadian clock. Cell. 2013;155(4):793-806. DOI 10.1016/j. cell.2013.10.026

Gawad C., Koh W., Quake S.R. Dissecting the clonal origins of childhood acute lymphoblastic leukemia by single-cell genomics. Proc. Natl. Acad. Sci. USA. 2014;111(50):17947-17952. DOI 10.1073/ pnas. 1420822111.

Gawad C., Koh W., Quake S.R. Single-cell genome sequencing: current state of the science. Nat. Rev. Genet. 2016;17(3):175-188. DOI 10.1038/nrg.2015.16.

Gerber T., Willscher E., Loeffler-Wirth H., Hopp L., Schadendorf D., Schartl M., Anderegg U., Camp G., Treutlein B., Binder H., Kunz M. Mapping heteroge-neity in patient-derived melanoma cultures by single-cell RNA-seq. Oncotarget. 2017;8(1):846-862. DOI 10.18632/oncotarget.13666.

Goldberg A.D., Allis C.D., Bernstein E. Epigenetics: a landscape takes shape. Cell. 2007;128(4):635-638.

Grun D., Lyubimova A., Kester L., Wiebrands K., Basak O., Sasaki N., Clevers H., Oudenaarden A. Single-cell messenger RNA sequencing reveals rare intestinal cell types. Nature. 2015;525(7568):251-255. DOI 10.1038/nature14966.

Hafner M., Landgraf P., Ludwig J., Rice A., Ojo T., Lin C., Holoch D., Lim C., Tuschl T. Identification of microRNAs and other small regulatory RNAs using cDNA library sequencing. Methods. 2008;44(1):3-12.

Haghverdi L., Büttner M., Wolf F.A., Buettner F., Theis F.J. Diffusion pseudotime robustly reconstructs lineage branching. Nat. Methods. 2016;13:845-848.

Ham R.G. Clonal growth of mammalian cells in a chemically defined, synthetic medium. Proc. Natl. Acad. Sci. USA. 1965;53:288-293.

Haque A., Engel J., Teichmann S.A., Lonnberg T. A practical guide to single-cell RNA-sequencing for biomedical research and clinical applications. Genome Med. 2017;9:75.

Hashimshony T., Senderovich N., Avital G., Klochendler A., Leeuw Y., Anavy L., Gennert D., Li S., Livak K.J., Rozenblatt-Rosen O., Dor Y., Regev A., Yanai I. CEL-Seq2: sensitive highly-multiplexed single-cell RNA-Seq. Genome Biol. 2016;17:77. DOI 10.1186/ s13059-016-0938-8.

Hashimshony T., Wagner F., Sher N., Yanai I. CEL-Seq: single-cell RNA-Seq by multiplexed linear amplification. Cell Rep. 2012;2(3): 666-673. DOI 10.1016/j.celrep.2012.08.003.

Hwang B., Lee J.H., Bang D. Single-cell RNA sequencing technologies and bioinformatics pipelines. Exp. Mol. Med. 2018;50:96.

Islam S., Zeisel A., Joost S., Manno G.L., Zajac P., Kasper M., Lonnerberg P., Linnarsson S. Quantitative single-cell RNA-seq with unique molecular identifiers. Nat. Methods. 2014;11(2):163-166. DOI 10.1038/nmeth.2772.

Jaitin D.A., Kenigsberg E., Keren-Shaul H., Elefant N., Paul F., Zaretsky I., Mildner A., Cohen N., Jung S., Tanay A., Amit I. Massively parallel single-cell RNA-seq for marker-free decomposition of tissues into cell types. Science. 2014;343(6172):776-779. DOI 10.1126/science. 1247651 . 
Jaitin D.A., Weiner A., Yofe I., Lara-Astiaso D., Kern-Shaul H., David E., Salame T.M., Tanay A., Oudenaarden A., Amit I. Dissecting immune circuits by linking CRISPR-pooled screens with single-cell RNA-seq. Cell. 2016;167(7):1883-1896. DOI 10.1016/j.cell.2016. 11.039 .

Janes K.A., Wang C.C., Holmberg K.J., Cabral K., Brugge J.S. Identifying single-cell molecular programs by stochastic profiling. Nat. Methods. 2010;7(4):311-317. DOI 10.1038/nmeth.1442.

Jiang L., Schlesinger F., Davis C.A., Zhang Y., Li R., Salit M., Gingeras T.R., Oliver B. Synthetic spike-in standards for RNA-seq experiments. Genome Res. 2011;21:1543-1551.

Junker J.P., Oudenaarden A. Every cell is special: genome-wide studies add a new dimension to single-cell biology. Cell. 2014;157(1):8-11. DOI 10.1016/j.cell.2014.02.010.

Kalhor R., Mali P., Church G.M. Rapidly evolving homing CRISPR barcodes. Nat. Methods. 2017;14(2):195-200. DOI 10.1038/nmeth. 4108.

Kamme F., Salunga R., Yu J., Tran D.T., Zhu J., Luo L., Bittner A., Guo H.Q., Miller N., Wan J., Erlander M. Single-cell microarray analysis in hippocampus CA1: demonstration and validation of cellular heterogeneity. J. Neurosci. 2003;23(9):3607-3615.

Klein A.M., Mazutis L., Akartuna I., Tallapragada N., Veres A., Li V., Peshkin L., Weitz D.A., Kirschner M.W. Droplet barcoding for single-cell transcriptomics applied to embryonic stem cells. Cell. 2015;161(5):1187-1201. DOI 10.1016/j.cell.2015.04.044.

Kolodziejczyk A.A., Kim J.K., Svensson V., Marioni J.C., Teichmann S.A. The technology and biology of single-cell RNA sequencing. Mol. Cell. 2015;58(4):610-620. DOI 10.1016/j.molcel.2015. 04.005.

Kumar P., Tan Y., Cahan P. Understanding development and stem cells using single cell-based analyses of gene expression. Development. 2017; 144:17-32. DOI 10.1242/dev.133058.

Landry Z.C., Giovanonni S.J., Quake S.R., Blainey P.C. Optofluidic cell selection from complex microbial communities for single-genome analysis. Methods Enzymol. 2013;531:61-90. DOI 10.1016/ B978-0-12-407863-5.00004-6.

Lavin Y., Kobayashi S., Leader A., Amir E.D., Elefant N., Bigenwald C., Remark R., Sweeney R., Becker C.D., Levine J.H., Meinhof K., Chow A., Kim-Shulze S., Wolf A., Medaglia C., Li H., Rytlewski J.A., Emerson R.O., Merad M. Innate immune landscape in early lung adenocarcinoma by paired single-cell analyses. Cell. 2017;169(4):750-765.e17. DOI 10.1016/j.cell.2017.04.014.

Leung M.L., Davis A., Gao R., Casasent A., Wang Y., Sei E., Vilar E., Maru D., Kopetz S., Navin N.E. Single-cell DNA sequencing reveals a late-dissemination model in metastatic colorectal cancer. Genome Res. 2017;27(8):1287-1299. DOI 10.1101/gr.209973.116.

Li B., Ruotti V., Stewart R.M., Thomson J.A., Dewey C.N. RNA-seq gene expression estimation with read mapping uncertainty. Bioinformatics. 2010;26:493-500

Li H., Courtois E.T., Sengupta D., Tan Y., Chen K.H., Goh J.J.L., Kong S.L., Chua C., Hon L.K., Tan W.S., Wong M., Choi P.J., Wee L.J.K., Hillmer A.M., Tan I.B., Robson P., Prabhakar S. Reference component analysis of single-cell transcriptomes elucidates cellular heterogeneity in human colorectal tumors. Nat. Genet. 2017; 49:708-718

Li J., Witten D.M., Johnstone I.M., Tibshirani R. Normalization, testing, and false discovery rate estimation for RNA-sequencing data. Biostatistics. 2012;13:523-538.

Lindström S., Andersson-Svahn H. Overview of single-cell analyses: microdevices and applications. Lab. Chip. 2010;10(24):3363-3372. DOI 10.1039/c0lc00150c.

Liu L., Li Y., Li S., Hu N., He Y., Pong R., Lin D., Lu L., Law M. Comparison of next-generation sequencing systems. J. Biomed. Biotechnol. 2012;2012:251364. DOI 10.1155/2012/251364

Ludwig L.S., Lareau C.A., Ulirsch J.C., Christian E., Muus C., Li L.H., Pelka K., Ge W., Oren Y., Brack A., Law T., Rodman C., Chen J.H., Boland G.M., Hacohen N., Rozenblatt-Rosen O., Aryee M.J., Buenrostro J.D., Regev A., Sankaran V.G. Lineage tracing in humans enabled by mitochondrial mutations and single-cell genomics. Cell. 2019;176(6);1325-1339. DOI 10.1016/j.cell.2019.01.022.

Lun A.T.L., Bach K., Marioni J.C. Pooling across cells to normalize single-cell RNA sequencing data with many zero counts. Genome Biol. 2016;17:75. DOI 10.1186/s13059-016-0947-7.

Maaten L. van der, Hinton G. Visualizing data using t-SNE. J. Mach. Learn. Res. 2008;9: 2579-2605.

Macosko E.Z., Basu A., Satija R., Nemesh J., Shekhar K., Goldman M., Tirosh I., Bialas A.R., Kamitaki N., Martersteck E.M., Trombetta J.J., Weitz D.A., Sanes J.R., Shalek A.K., Regev A., McCarroll S.A. Highly parallel genome-wide expression profiling of individual cells using nanoliter droplets. Cell. 2015;161(5):1202-1214. DOI 10.1016/j.cell.2015.05.002.

Mahata B., Zhang X., Kolodziejczyk A.A., Proserpio V., Haim-Vilmovsky L., Taylor A.E., Hebenstreit D., Dingler F.A., Moignard V., Gottgens B., Arlt W., McKenzie A.N.J., Teichmann S.A. Single-cell RNA sequencing reveals $T$ helper cells synthesizing steroids de novo to contribute to immune homeostasis. Cell Rep. 2014;7(4):11301142. DOI 10.1016/j.celrep.2014.04.011.

Marcus J.S., Anderson W.F., Quake S.R. Microfluidic single-cell mRNA isolation and analysis. Anal. Chem. 2006;78(9):3084-3089.

Mazutis L., Gilbert J., Ung W.L., Weitz D.A., Griffiths A.D., Heyman J.A. Single-cell analysis and sorting using droplet-based microfluidics. Nat. Protoc. 2013;8(5):870-891. DOI 10.1038/ nprot.2013.046.

McKenna A., Findlay G.M., Gagnon J.A., Horwitz M.S., Schier A.F., Shendure J. Whole-organism lineage tracing by combinatorial and cumulative genome editing. Science. 2016;353(6298):aaf7907. DOI 10.1126/science.aaf7907.

Mi D., Li Z., Lim L., Li M., Moissidis M., Yang Y., Gao T., Hu T.X., Pratt T., Price D.J., Sestan N., Marin O. Early emergence of cortical interneuron diversity in the mouse embryo. Science. 2018;360 (6384):81-85. DOI 10.1126/science.aar6821.

Moon K.R., Dijk D., Wang Z., Burkhardt D., Chen W.S., Yim K., Elen A., Hirn M.J., Coifman R.R., Ivanova N.B., Wolf G., Krishnaswamy S. Visualizing structure and transitions for biological data exploration. Cell. 2018;65. http://dx.doi.org/10.2139/ssrn.3155891.

Moroz L.L. NeuroSystematics and periodic system of neurons: model vs reference species at single-cell resolution. ACS Chem. Neurosci. 2018;9:1884-1903. DOI 10.1021/acschemneuro.8b00100.

Moroz L.L., Edwards J.R., Puthanveettil S.V., Kohn A.B., Ha T., Heyland A., Knudsen B., Sahni A., Yu F., Liu L., Jezzini S., Lovell P., Iannucculli W., Chen M., Nguyen T., Sheng H., Shaw R., Kalachikov S., Panchin Y.V., Farmerie W., Russo J.J., Ju J., Kandel E.R. Neuronal transcriptome of Aplysia: neuronal compartments and circuitry. Cell. 2006;127(7):1453-1467.

Mortazavi A., Williams B.A., McCue K., Schaeffer L., Wold B. Mapping and quantifying mammalian transcriptomes by RNA-seq. Nat. Methods. 2008;5:621-628.

Nagano T., Lubling Y., Stevens T.J., Schoenfelder S., Yaffe E., Dean W., Laue E.D., Tanay A., Fraser P. Single-cell Hi-C reveals cell-to-cell variability in chromosome structure. Nature. 2013;502(7469):59-64. DOI 10.1038/nature12593.

Nagano T., Lubling Y., Varnai C., Dudley C., Leung W., Baran Y., Cohen N.M., Wingett S., Fraser P., Tanay A. Cell-cycle dynamics of chromosomal organization at single-cell resolution. Nature. 2017; 547(7661):61-67. DOI 10.1038/nature23001.

Navin N., Kendall J., Troge J., Andrews P., Rodgers L., McIndoo J., Cook K., Stepansky A., Levy D., Esposito D., Muthuswamy L., Krasnitz A., McCombie W.R., Hicks J., Wingler M. Tumour evolution inferred by single-cell sequencing. Nature. 2011;472(7341): 90-94. DOI 10.1038/nature09807.

Nikolenko S.I., Korobeynikov A.I., Alekseyev M.A. BayesHammer: Bayesian clustering for error correction in single-cell sequencing. BMC Genomics. 2013;14(Suppl. 1):S7. DOI 10.1186/1471-216414-S1-S7.

Nowogrodzki A. The cell seeker. Nature. 2017;547:24-26.

Okaty B.W., Freret M.E., Rood B.D., Brust R.D., Hennessy M.L., Bai- 
ros D., Kim J.C., Cook M.N., Dymecki S.M. Multi-scale molecular deconstruction of the serotonin neuron system. Neuron. 2015; 88(4):774-791. DOI 10.1016/j.neuron.2015.10.007.

Parekh S., Ziegenhain C., Vieth B., Enard W., Hellmann I. zUMIs A fast and flexible pipeline to process RNA sequencing data with UMIs. GigaScience. 2018;7(6). DOI 10.1093/gigascience/giy059.

Pierson E., Yau C., ZIFA: Dimensionality reduction for zero-inflated single-cell gene expression analysis. Genome Biol. 2015;16:241. DOI 10.1186/s13059-015-0805-z.

Pijuan-Sala B., Griffiths J.A., Guibentif C., Hiscock T.W., Jawaid W., Calero-Nieto F.J., Mulas C., Ibarra-Soria X., Tyser R.C.V., Ho D.L.L., Reik W., Srinivas S., Simons B.D., Nihols J., Marioni J.C., Gottgens B. A single-cell molecular map of mouse gastrulation and early organogenesis. Nature. 2019;566;490-495. DOI 10.1038/s41586-019-0933-9.

Poulin J.F., Tasic B., Hjerling-Leffler J., Trimarchi J.M., Awatramani R. Disentangling neural cell diversity using single-cell transcriptomics. Nat. Neurosci. 2016;19(9):1131-1141. DOI 10.1038/nn.4366.

Qiu X., Mao Q., Tang Y., Wang L., Chawla R., Pliner H., Trapnell C. Reversed graph embedding resolves complex single-cell developmental trajectories. Nat. Methods. 2017;14(10):979-982. DOI 10.1038/nmeth.4402.

Ramsköld D., Luo S., Wang Y.C., Li R., Deng Q., Faridani O.R., Daniels G.A., Khrebtukova I., Loring J.F., Laurent L.C., Schroth G.P., Sandberg R. Full-length mRNA-Seq from single-cell levels of RNA and individual circulating tumor cells. Nat. Biotechnol. 2012; 30(8):777-782.

Robinson M.D., Oshlack A. A scaling normalization method for differential expression analysis of RNA-seq data. Genome Biol. 2010; 11:R25. DOI 10.1186/gb-2010-11-3-r25.

Rotem A., Ram O., Shoresh N., Sperling R.A., Goren A., Weitz D.A., Bernstein B.E. Single-cell ChIP-seq reveals cell subpopulations defined by chromatin state. Nat. Biotechnol. 2015;33(11):1165-1172. DOI $10.1038 /$ nbt.3383.

Salafi T., Zeming K.K., Zhang Y. Advancements in microfluidics for nanoparticle separation. Lab. Chip. 2016;17(1):11-33.

Saliba A.E., Westermann A.J., Gorski S.A., Vogel J. Single-cell RNAseq: advances and future challenges. Nucleic Acids Res. 2014; 42(14):8845-8860. DOI 10.1093/nar/gku555.

Sassagawa Y., Danno H., Takada H., Ebisawa M., Tanaka K., Hayashi T., Kurisaki A., Nikaido I. Quartz-Seq2: a high-throughput single-cell RNA-sequencing method that effectively uses limited sequence reads. Genome Biol. 2018;19:29. DOI 10.1186/s13059018-1407-3.

Schwartz S., Agarwala S.D., Mumbach M.R., Jovanovic M., Mertins P., Shishkin A., Tabach Y., Mikkelsen T.S., Satija R., Ruvkun G., Carr S.A., Lander E.S., Fink G.R., Regev A. High-resolution mapping reveals a conserved, widespread, dynamic mRNA methylation program in yeast meiosis. Cell. 2013;155(6):1409-1421. DOI 10.1016/j.cell.2013.10.047.

Segal E., Friedman N., Koller D., Regev A. A module map showing conditional activity of expression modules in cancer. Nat. Genet. 2004;36(10):1090-1098.

Segerstolpe A., Palasantza A., Eliasson P., Andersson E.M., Andreasson A.C., Sun X., Picelli S., Sabirsh A., Clausen M., Bjursell M.K., Smith D.M., Kasper M., Ammala C., Sandberg R. Single-cell transcriptome profiling of human pancreatic islets in health and type 2 diabetes. Cell Metab. 2016;24:593-607. DOI 10.1016/j.cmet.2016. 08.020 .

Shalek A.K., Satija R., Adiconis X., Gertner R.S., Gaublomme J.T., Raychowdhury R., Schwartz S., Yosef N., Malboeuf C., Lu D., Trombetta J.J., Gennert D., Gnirke A., Goren A., Hacohen N., Levin J.Z., Park H., Regev A. Single-cell transcriptomics reveals bimodality in expression and splicing in immune cells. Nature. 2013; 498(7453):236-240. DOI 10.1038/nature12172.

Soumillon M., Cacchiarelli D., Semrau S., van Oudenaarden A., Mikkelsen T.S. Characterization of directed differentiation by high-throughput single-cell RNA-seq. bioRxiv. 2014. DOI 10.1101/003236.
Stegle O., Teichmann S.A., Marioni J.C. Computational and analytical challenges in single-cell transcriptomics. Nat. Rev. Genet. 2015;16(3):133-145. DOI 10.1038/nrg3833.

Stevens T.J., Lando D., Basu S., Atkinson L.P., Cao Y., Lee S.F., Leeb M., Wohlfahrt K.J., Boucher W., O’Shaughnessy-Kirwan A., Cramard J., Faure A.J., Ralser M., Blanco E., Morey L., Sanso M., Palayret M.G.S., Lehner B., Croce L.D., Wutz A., Hendrich B., Klenerman D., Laue E.D. 3D structures of individual mammalian genomes studied by single-cell Hi-C. Nature. 2017;544(7648):59-64. DOI 10.1038/nature21429.

Subkhankulova T., Gilchrist M.J., Livesey F.J. Modelling and measuring single cell RNA expression levels find considerable transcriptional differences among phenotypically identical cells. BMC Genomics. 2008;9:268. DOI 10.1186/1471-2164-9-268.

Tang F., Barbacioru C., Wang Y., Nordman E., Lee C., Xu N., Wang X., Bodeau J., Tuch B.B., Siddiqui A., Lao K., Surani M.A. mRNA-Seq whole-transcriptome analysis of a single cell. Nat. Methods. 2009; 6(5):377-382. DOI 10.1038/nmeth.1315. Epub 2009 Apr 6.

Taylor D.M., Aronow B.J. The pediatric cell atlas: defining the growth phase of human development at single-cell resolution. Dev. Cell. 2019;49. DOI 10.1016/j.devcel.2019.03.001.

Tian L., Su S., Dong X., Amann-Zalcenstein D., Biben C., Seidi A., Hilton D.J., Naik S.H., Ritchie M.E. scPipe: a flexible R/Bioconductor preprocessing pipeline for single-cell RNA-sequencing data. PLoS Comput. Biol. 2018;14(8):e100636. DOI 10.1371/journal. pcbi.1006361.

Tirosh I., Izar B., Prakadan S.M., Wadsworth M.H., Treacy D., Trombetta J.J., Rotem A., Rodman C., Lian C., Murphy G., Fallahi-Sichani M., Dutton-Regester K., Lin J.-R., Cohen O., Shah P., Lu D., Genshaft A.S., Hughes T.K., Ziegler C.G.K., Kazer S.W., Gaillard A., Kolb K.E., Villani A.C., Johannessen C.M., Andreev A.Y., Allen E.M.V., Bertagnolli M., Sorger P.K., Sullivan R.J., Flaherty K.T., Frederick D.T., Jane-Valbuena J., Yoon C.H., Rozenblatt-Rosen O., Shalek A.K., Regev A., Garraway L.A. Dissecting the multicellular ecosystem of metastatic melanoma by single-cell RNA-seq. Science. 2016;352(6282):189-196. DOI 10.1126/science.aad0501.

Tokunaga T., Hirose O., Kawaguchi S., Toyoshima Y., Teramoto T., Ikebata H., Kuge S., Ishihara T., Iino Y., Yoshida R. Automated detection and tracking of many cells by using $4 \mathrm{D}$ live-cell imaging data. Bioinformatics. 2014;30:43-51.

Trapnell C., Cacchiarelli D., Grimsby J., Pokharel P., Li S., Morse M., Lennon N.J., Livak K.J., Mikkelsen T.S., Rinn J.L. The dynamics and regulators of cell fate decisions are revealed by pseudotemporal ordering of single cells. Nat. Biotechnol. 2014;32(4):381-386. DOI 10.1038/nbt.2859.

Treutlein B., Brownfield D.G., Wu A.R., Neff N., Mantalas G.L., Espinoza F.H., Desai T.J., Krasnow M.A., Quake S.R. Reconstructing lineage hierarchies of the distal lung epithelium using single-cell RNA-seq. Nature. 2014;509(7500):371-375. DOI 10.1038/nature 13173.

Valihrach L., Androvic P., Kubista M. Platforms for single-cell collection and analysis. Int. J. Mol. Sci. 2018;19:807.

Wang J., Song Y. Single cell sequencing: a distinct new field. Clin. Transl. Med. 2017;6(1):10. DOI 10.1186/s40169-017-0139-4.

Wang Y., Navin N.E. Advances and applications of single-cell sequencing technologies. Mol. Cell. 2015;58(4):598-609. DOI 10.1016/j. molcel.2015.05.005.

Whitesides G.M. The origins and the future of microfluidics. Nature. 2006;442(7101):368-373.

Wolf F.A., Angerer P., Theis F.J. SCANPY: large-scale single-cell gene expression data analysis. Genome Biol. 2018;19(1):15. DOI 10.1186/s13059-017-1382-0.

Yu P., Lin W. Single-cell transcriptome study as big data. Genom. Proteom. Bioinf. 2016;14:21-30.

Zeisel A., Munoz-Manchado A.B., Codeluppi S., Lonnerberg P., Manno G., Jureus A., Margues S., Munguba H., He L., Betsholtz C., Rolny C., Castelo-Branco G., Hjerling-Leffler J., Linnarsson S. Cell 
types in the mouse cortex and hippocampus revealed by singlecell RNA-seq. Science. 2015;347(6226):1138-1142. DOI 10.1126/ science.aaa1934.

Zhao C., Hu S., Huo X., Zhang Y. Dr.seq2: a quality control and analysis pipeline for parallel single cell transcriptome and epigenome data. PLoS One. 2017;12(7):e0180583. DOI 10.1371/journal.pone. 0180583.

Zheng G.X., Terry J.M., Belgrader P., Ryvkin P., Bent Z.W., Wilson R., Ziraldo S.B., Wheeler T.D., McDermott G.P., Zhu J., Gregory M.T., Shuga J., Montesclaros L., Underwood J.G., Masquelier D.A.,
Nishimura S.Y., Schnall-Levin M., Wyatt P.W., Hindson C.M., Bharadwaj R., Wong A., Ness K.D., Beppu L.W., Deeg H.J., McFarland C., Loeb K.R., Valente W.J., Ericson N.G., Stevens E.A., Radich J.P., Mikkelsen T.S., Hindson B.J., Bielas J.H. Massively parallel digital transcriptional profiling of single cells. Nat. Commun. 2017;8:14049. DOI 10.1038/ncomms14049.

Ziegenhain C., Vieth B., Parekh S., Reinius B., Guillaumet-Adkins A., Smets M., Leonhardt H., Heyn H., Hellmann I., Enard W. Comparative analysis of single-cell RNA sequencing methods. Mol. Cell. 2017;65:631-643. DOI 10.1015/j.molcel.2017.01.023.

ORCID ID

E.A. Vodiasova orcid.org/0000-0003-3886-2880

E.S. Chelebieva orcid.org/0000-0002-7662-2573

O.N. Kuleshova orcid.org/0000-0003-3745-7066

Acknowledgements. The research were supported by the Government of the Russian Federation, grant No. 14.W03.31.0015..

Conflict of interest. The authors declare no conflict of interest.

Received September 14, 2018. Revised May 30, 2019. Accepted May 30, 2019. 